\title{
Y Chromosome
}

National Human Genome Research Institute (NHGRI)

\section{Source}

National Human Genome Research Institute (NHGRI). Y Chromosome.

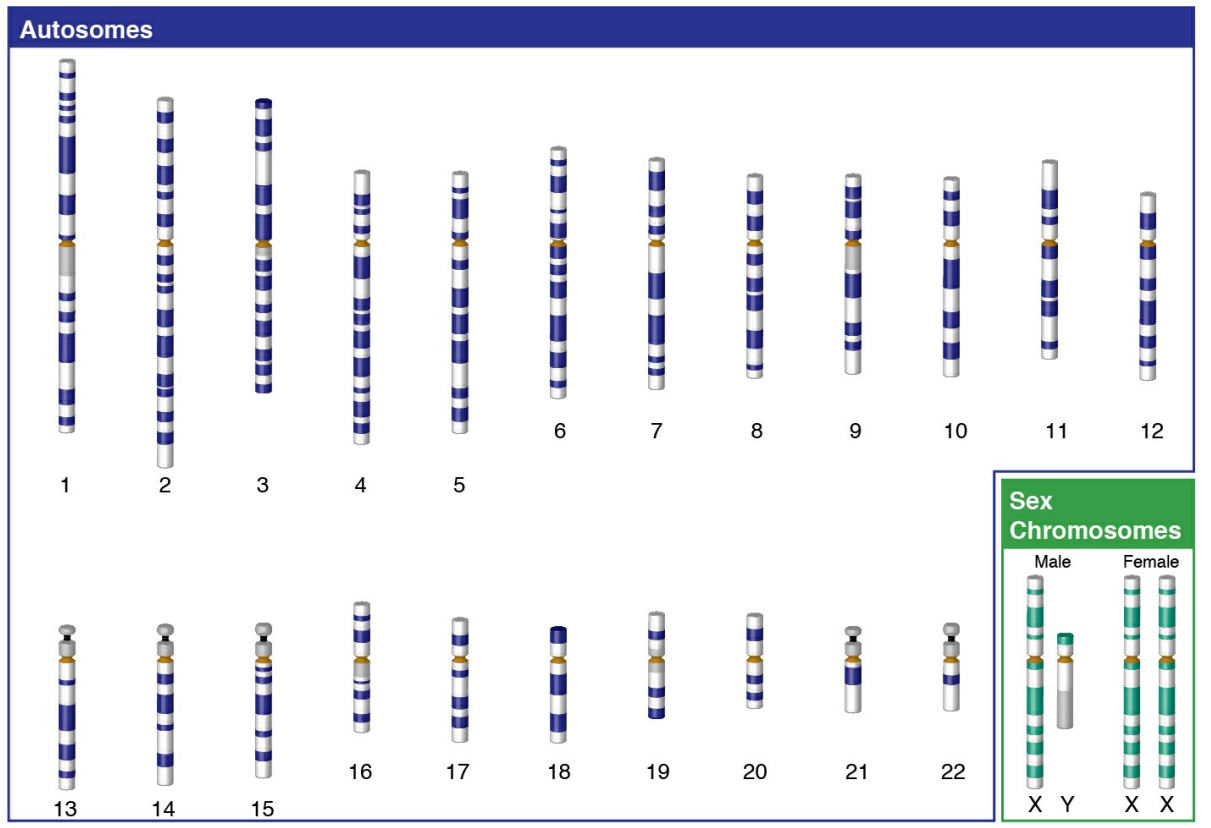

The $Y$ chromosome is one of two sex chromosomes. Humans and other mammals have two sex chromosomes, the $\mathrm{X}$ and the $\mathrm{Y}$. Females have two $\mathrm{X}$ chromosomes in their cells, while males have $X$ and $Y$ chromosomes in their cells. Egg cells contain an $X$ chromosome, while sperm cells contain an X or a Y chromosome. This arrangement means that during fertilization, it is the male that determines the sex of the offspring. 